\title{
NOREGS BANKS HISTORIE I EIT LANGSIKTIG JURIDISK PERSPEKTIV
}

I historia til Noregs Bank har organiseringa vore viktig for oppnå sentrale mål som monetær stabilitet og samstundes iallfall ein viss grad av politisk kontroll. Dette blei søkt nådd ved å la banken frå 1816 vere eit privat aksjeselskap med spesielle styringsordningar. Men stillinga til private aksjeeigarar var verna av grunnlova på ein måte som la skrankar for seinare politiske initiativ. Då staten overtok alle aksjane i 1949, blei det i staden spørsmål om ein særleg grunnlovsregel gav regjeringa krav på å kunne kontrollere og instruere banken. I den seinaste tida står dette opp mot den nyare internasjonale tendensen til at sentralbankar er meir uavhengige.

Ola Mestad

Professor dr. juris ved Det juridiske fakultet, Universitetet i Oslo.

ola.mestad@jus.uio.no

\section{The history of the Norwegian Central bank in a legal long term perspective}

\begin{abstract}
The main feature of the article is analysis of the different legal structures used through the 200 years history of the Norwegian central bank (Norges Bank) and the legal constraints that those structures establish when seen in the context of constitutional law. In the Norwegian Constitution of 1814, no provision on a central bank was adopted even if it had been proposed by several drafters. But in the autumn, in preparation for the forced union with Sweden, a provision was put into the Constitution to preserve Norway's monetary and banking autonomy against Swedish possible amalgamation of institutions. Norges Bank was then established based on international models as a private limited liability company in 1816 with a monopoly to issue bank notes. The choice of organization was based on the goal of monetary stability. Since the establishment had to follow a forced model to get in place the joint stock in form of a silver fund, special rules on the organization were adopted, giving Parliament (the Storting) the right to appoint all members of the governing bodies of the bank. The shareholders, however, who had been forced to take shares, were as a starting point, the sole recipients of dividend. The article studies the different limitations that constitutional protection of shareholders put on monetary policy. In 1949, an expropriation
\end{abstract}


statute was adopted that, against compensation, transferred all shares to the state. This again raised questions of the constitutional prerogative of the government to control and instruct management of state property. The prerogative question has two sides, one with respect to the role of the Storting and another with respect to the independence of the bank itself. Of recently, the latter question has again come to the forefront, partly due to newer international policy trends of independent central banks.

\section{Key words}

Independent Central Bank, Joint Stock Company, Royal Prerogative, Norwegian Constitution, Constitutional protection

\section{Innleiing}

No har Noregs Bank fått si viktige historie gjennom 200 år behandla på ein framståande og innsiktsgivande måte i boka Norges Bank 1816-2016. ${ }^{1}$ Verket inntar både $ø$ konomiske, finanspolitiske og allmennpolitiske perspektiv, så vel som institusjonelle og, til ein viss grad, juridiske. Her i artikkelen er det søkt å følgje nokre få juridiske perspektiv og til dels å gå djupare inn i dei enn det som skjer i boka. ${ }^{2}$ Det sentrale temaet her er organiseringa av banken, ikkje korleis den har utøvd si skiftande verksemd som setelbank og seinare sentralbank, og endå mykje seinare også som forvaltar av Statens pensjonsfond utland. Eit kjernespørsmål ved organiseringa er den valde institusjonsforma, gjennom 169 år fram til 1985 som aksjeselskap, mesteparten av denne tida, fram til 1949, med heilt eller iallfall dominerande privat eigarskap. Men det var eit aksjeselskap med særskilde privileg. Viktigast var eineretten - monopolet - til å utgi pengesetlar, som formelt kom på plass i 1818.

Aksjeselskapsforma var meint å sikre at banken var uavhengig av kongemakta, seinare regjeringa, samstundes som den, sjølv om den ofte blei karakterisert som Stortingets bank, heller ikkje kunne instruerast av dette. Då sentralbanklova blei vedtatt i 1985, heldt banken

\footnotetext{
${ }^{1}$ Einar Lie, Jan Thomas Kobberrød, Eivind Thomassen og Gjermund Forfang Rongved, Norges Bank 1816-2016, Oslo 2016.

2 Takk til Hans Jacob Bull, Even Lange og Einar Lie for kommentarar til eit utkast til artikkelen, og til innspel frå deltakarar på Noregs Bank-seminaret i Det Norske Videnskaps-Akademi 11. november 2016.
} 
fram som ein sjølvstendig institusjon, eit eige rettssubjekt, men underlagd ein særskilt regulert instruksjonsrett frå Kongen i statsråd, ikkje frå finansministeren eller departementet.

Den valde organiseringa reiste både spesielle selskapsrettslege og stats- og forvaltningsrettslege spørsmål. Mange av spørsmåla har no mest historisk interesse, men fleire av dei stats- og forvaltningsrettslege spørsmåla er i dag aktuelle på nye måtar. Det skal vi sjå på mot slutten av artikkelen.

Den valde organisasjonsforma for banken med eit privilegert privat aksjeselskap gjorde at seinare politisk ønskelege lovendringar måtte ta omsyn til det vernet som grunnlova gav for tildelte privileg og for privat eigedomsrett. Det gjaldt $§ 97$ med sitt forbod mot tilbakeverkande lover og $\S 105$ som forbaud ekspropriasjon utan erstatning. Då banken blei statseigedom i 1949, oppstod i staden spørsmål om verknaden av grunnlova $§ 19$ om forvaltning av statseigedom. I tillegg var banken i ein lengre periode særskilt regulert i grunnlova § 110, og den kom i 2016 inn igjen, i § 33. Også særskilde selskapsrettslege spørsmål blei reist fordi den valde organiseringa ikkje var heilt som i andre aksjeselskap med ei sterk generalforsamling. I banken var det i staden eit sterkt representantskap, som formelt var det høgaste organet. ${ }^{3}$

Frå 1816 til i dag har det vore tre hovudlover om Noregs Bank: Fundatsen av 1816, Noregs Bank-lova av 1892 og sentralbanklova av 1985. Alle desse vil vi kome inn på. Datoen for sanksjon av lova som inneheldt fundatsen, 14. juni 1816, var utgangspunktet for Noregs Banks 200-årsjubileum.

\section{Riksforsamling, grunnlov og bankspørsmålet}

Noregs Banks rettshistorie byrjar på Riksforsamlinga sjølv om banken, overraskande for nokon, ikkje blei vedtatt oppretta der. Fleire av dei innsende og framlagde grunnlovsutkasta våren 1814 hadde reglar om ein bank, gjerne organisert som aksjeselskap. I sorenskrivar Lauritz Weidemanns utkast $§ 66$ er det særskilt fastsett at ein eventuell bank skulle vere ein privat aksjebank:

\footnotetext{
${ }^{3}$ Ein del av det selskaps- og statsrettslege stoffet i dei første delane av artikkelen byggjer på Ola Mestad, Noregs Bank som aksjeselskap i 1816 - selskapsrettsleg forankring av stabilt pengevesen, i Gudmund Knudsen, Geir Woxholth og Kristin Normann (red.), Selskap, kontrakt, konkurs og rettskilder. Festskrift til Mads Henry Andenæs 70 år, Oslo 2010: 207-220. På ein del punkt går framstillinga her lenger, og på mange meir selskapsrettslege spørsmål går framstillinga der djupare.
} 
"Skulde Kongen finde det tjenligt at octroiere Rigs- Stats- eller andre Banqver; saa skulle disse altid forblive private, i Landet bosatte Actiehaveres Eiendom, hvorudi Regjeringen og Statens Kasse ingen Deel eller Actie kunde have."

I same paragraf la han til: "Regjeringens Beviser for Penge og Banqvens Papiirpenge maa aldrig tillægges noget tvunget Værd." Regelen skulle "forekomme Statsgjeld og indirecte store Skatter". ${ }^{4}$ Det sentrale synest å vere at banken måtte vere privat for at ikkje regjeringa

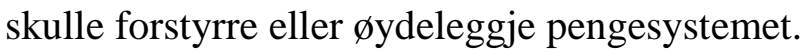

Dømt ut frå grunnlovsutkasta var det gjennomgåande eit ønske om at den nasjonale banken skulle vere ein privateigd aksjebank. ${ }^{5}$ Men i Eidsvollgrunnlova vart ingenting tatt inn om bankspørsmål. Det som låg nærmast var vedtaket i $§ 75 \mathrm{c} \mathrm{om}$ at det ligg til Stortinget å "føre Opsyn med Rigets Pengevæsen”.

Også regenten Christian Frederik ønskte regulering av ein bank og noterte litt forbløffa i dagboka si for 14. mai at det ikkje vart vedtatt: «Noget ganske underlig skedde i dag, nemlig at nationalbanken, en institution som folket saa ofte har ønsket og krævd, blev utsat til næste riksforsamling.» Eit «misgrep»kalte han dette. ${ }^{6}$ Korleis det skjedde er først no i 2014 forklart av Martin Austnes i hans doktoravhandling. Ikkje eingong prinsens eigen $\emptyset$ konomiregjeringsråd Carsten Tank støtta bankforslaget frå prinsen, som blei forkasta med 72 mot 31 røyster. Grunnen var at Riksforsamlinga ikkje ville ha ein statsbank som samstundes var involvert i statsfinansane. ${ }^{7}$

Riksforsamlinga vedtok i staden å overlate til det første ordentlege storting å avgjere "Forslag fra den nedsatte Finants Commitee, - angaaende Planen til en ny Banke for Riget". ${ }^{8}$ Forslaget frå komiteen som var leia av grev Wedel-Jarlsberg, kjem vi tilbake til nedanfor.

Men i mellomtida heldt Christian Frederik fast ved behovet for bank. Etter at stormaktskommissærane i juni/juli 1814 hadde kome til Christiania og overtydd den nyvalde

\footnotetext{
${ }^{4}$ Riksforsamlingens forhandlinger I, Kristiania 1914: 150. Weidemann skal òg ha skrive eit eige utkast til banklov, sjå Norsk biografisk leksikon, nettutgåva, artikkel om Weidemann.

${ }^{5}$ M.a. ville sorenskrivar Arnoldus Koren i sitt utkast ha ein privat aksjebank, sjå Riksforsamlingens forhandlinger I: 159. Det finst nokre fleire utkast som inneheld noko om banksaka enn dei vi har gjengitt her, sjå registeret i Riksforsamlingens forhandlinger, Tillægsdel, Kristiania 1918, stikkordet Bankvæsen.

${ }^{6}$ Kong Christian Frederiks Dagbok fra hans ophold i Norge i 1814, Kristiania 1914: 211.

${ }^{7}$ Sjå Riksforsamlingens forhandlinger I: 60 og Martin Austnes, Kampen om banken. Et historisk perspektiv på utformingen av det nye Norges bank- og pengevesen ca. 1814-1816, Norges Banks skriftserie 50/2016: 109114, opphavleg Ph.D.-avhandling, UiO 2014.

${ }^{8}$ Riksforsamlingens forhandlinger I: 401, jf. s. 66 og Storthings-Efterretninger 1814-1833, bd. I (1874): 107.
} 
kongen om at det ikkje fanst støtte til eit heilt sjølvstendig Noreg, utarbeidde han eit grunnlovsutkast med sikte på den komande unionen med Sverige. Der var bank og pengevesen viktige punkt. I sitt utkast frå 5. juli, der han både tok opp endringar og tillegg til Eidsvollsgrunnlova, skreiv han at det måtte kome tillegg med følgjande innhald:

«1. Rigets Pengevæsen sammenblandes ej med Sverriges. ---

4. En Bank for Norge uden Sammenblanding med Finanzerne eller med nærværende Rigsbank hvis Representativer efterhaanden ved directe Paalæg maae indløses indrettes."9 Utforminga av forslaget ser ut til å ha tatt lærdom av nederlaget på Eidsvoll. Statsrådet slutta seg til, og Christian Frederik sendte kravet til Karl Johan med kommissærane som vilkåra for ein union. Den svenske kongen måtte for det første godta grunnlova «som den norske nasjonen sjølv hadde gitt seg på Eidsvoll» med nødvendige endringar. For det andre følgde ei opplisting av ei rekkje krav som den svenske kongen måtte sikre kongedømet Noreg. Fremst av desse stod kravet om ein særskild bank for Noreg, slik som Stortinget finn å ville etablere den. ${ }^{10}$

Krava om bank og myntvesen blei ikkje tatt opp i dei ulike grunnlovsforslaga som blei utarbeidd på svensk side, men stortingskomiteen som var oppnemnt «til at modtage Meddelelser fra de Svenske Commissarier», tok opp spørsmålet i sitt første møte med dei den 17. oktober. Dei svarte at «Norge beholder sit eget Pengevæsen og sin egen bank, ifald Folket selv vil». ${ }^{11}$ Dermed blei det kontinuitet mellom det kravet som Christian Frederik og det norske statsrådet hadde stilt opp om sommaren og det som Stortinget kravde om hausten. ${ }^{12}$

Den endelege ordlyden i grunnlova $§ 110$ blei den 4. november: "Norge beholder sin egen Bank og sit eget Penge- og Myntvæsen, hvilke Indretninger ved Lov bestemmes.” Og det skjedde på det første ordentlege stortinget i 1816.

\footnotetext{
${ }^{9}$ Yngvar Nielsen, Bidrag til Norges Historie i 1814, bd. II, Christiania 1866: 269-270.

${ }_{10}$ Nielsen 1866: 308-309 [mi omsetjing].

${ }^{11}$ Storthings Forhandlinger i Aaret 1814, Christiania 1835: 320, jf. s. 317.

12 Initiativet frå Christian Frederik og det norske statsrådet om sommaren 1814, og kontinuiteten i dette fram til kravet frå meddelelseskomiteen, er ikkje med i framstillinga hos Austnes, og dermed framstår grev Wedel som meir sentral i dette spørsmålet under det overordentlege stortinget enn eg meiner det er grunnlag for, sjå Austnes 2016: 122-124. Som Austnes nemner, kom ikkje Wedel sjølv med i meddelelseskomiteen før 26. oktober, sjå Austnes 2016: 124. Statsrådet var det same som heldt fram om hausten, berre supplert med to stortingsoppnemnde medlemer den 13. oktober, sjå Ola Mestad, Christian Frederiks skygge. Kongespørsmålet under det overordentlege stortinget, i Ruth Hemstad og Bjørn Arne Steine (red.), Overgangstid. Forargelse og forsoning høsten 1814, Oslo 2016: 113-139 på s. 121.
} 
Tillegget i grunnlovsføresegna om at innretninga skulle fastsetjast ved lov, kom frå grev Wedel i Stortinget. Det er ikkje klart korfor han fremja tilleggsforslaget. Men det kan tenkjast at han, som visste han ville bli minister under den framtidige svenske og norske kongen, ved det ville syte for at kongemakta fekk innverknad på banken gjennom kongens suspensive veto i lovsaker. Elles kunne det tenkjast at føresegna blei lesen slik at den la kompetansen til å fastsetje reglar om banken direkte til Stortinget i plenarvedtak.

Frå våren til hausten 1814 hadde det dermed skjedd ei funksjonsendring av den påtenkte bankreguleringa i grunnlova. Om våren gjaldt spørsmålet den nasjonale ordninga av pengevesenet og kor uavhengig ein bank skulle vere av den nasjonale kongemakta, om hausten var det i staden spørsmål om å vere uavhengig av den dominerande unionspartneren Sverige.

\section{Første forsøk: Ein «Octroi for en Norsk Species-Bank»}

Til det første ordentlege stortinget i 1815 la den finanskomiteen som Riksforsamlinga hadde oppnemnd, fram sitt framlegg til en "Octroi for en Norsk Species-Bank". ${ }^{13}$ Ein oktroi var under einveldet eit instrument som gav selskap "monopolstilling og andre fordele som modstykke til kravet om en bestemt styreform og kontrol". ${ }^{14}$ Oktroien inntok ei mellomstilling mellom lov og ein endå meir bindande kontrakt. At komiteen brukte ordet var truleg uttrykk for eit ønske om stabilitet ved at reglane om banken ikkje lett skulle kunne endrast, eller eventuelt berre tradisjon frå Danmark-Noreg.

Finanskomiteen følgde opp tankane frå Eidsvoll og ville ha ein privat bank organisert som aksjeselskap, kalt interessentskap. Det gjekk fram m.a. av § 1 første punktum:

"Banken skal føre Navn af den Norske Specie-Bank, og stedse agtes og ansees, som en til almindeligt Gavn, ved privat Formue stiftet offentlig Indretning, og derfor uforanderligen staae under dens Interessentskab selv, og bestyres af Mænd, hvilke bemeldte Interessentskab, saaledes som i det følgende meldes, dertil frivilligen vælger."

\footnotetext{
${ }^{13}$ Datert 30. juni 1815. Trykt hos Jacob Lehmann, Christiania 1815, tilgjengeleg elektronisk frå Nasjonalbiblioteket. Utkastet vaklar mellom å skrive Species- og Specie-Bank. Det er også trykt i Historiske Samlinger udgivne af Den Norske Historiske Kildeskriftkommision, Andet bind, Andet hefte, Christiania 1905: 266-292.

${ }^{14}$ Thøger Nielsen, Træk af dansk aktieselskabsrets historie, Ugeskrift for Retsvæsen, 1954B: 193-203 på s. 194.
} 
Banken skulle ha rett til å utgi «Species-Sedler» som skulle vere tvingande betalingsmiddel $\left(\S \S 2\right.$ og 7). ${ }^{15}$ For setlane skulle banken ha sølvinnløysingsplikt.

Organiseringa av banken var tredelt med generalforsamling, representantskap og direksjon. Representantskapet med sine femten medlemer var sett i framgrunnen som det viktigaste styringsorganet. Det var òg representantskapet, ikkje generalforsamlinga, som skulle avgjere kor mykje utbyte som skulle delast ut til aksjeeigarane av gevinsten frå året før. Med seinare tids aksjeselskapsrettslege auge, verkar dette uvanleg. Framover 1800-talet blei det klart nok den generelle regel at det var generalforsamlinga i eit aksjeselskap som skulle fastsetje overskot og utbyte, og som kunne, om eit fleirtal ville, instruere selskapsleiinga.

Direktørane skulle vere fem i alt og veljast av representantskapet, jf. § 43. Både dei og medlemene av representantskapet måtte vere aksjeeigarar i banken. Men posisjonane skulle ikkje avhenge av kor mange aksjar kvar hadde, "da Kundskab og Duelighed til disse Forretninger ikke rette sig efter Actiers Antal”, som det så klokt og i tråd med egalitære prinsipp heitte i $\S 44$.

Med direktørvervet skulle følgje heider: "skjønt de ikke af Kongen udnævnes", skulle direktørane, "da de forestaae et for Staten saare vigtigt Verk, agtes og ansees som Statens egne Embedsmænd". I tillegg skulle dei innplasserast i rangordninga med en "passende Rang” som dei òg skulle ha etter at direktørtida var omme, jf. $§ 72$.

Det sentrale styrande dokumentet for banken skulle vere oktroien, som vel var tenkt vedtatt som lov og som i følgje utkastet "er og bliver altid bankens Grundlov". Nettopp i 1815 er det påfallande med bruken av ordet grunnlov som hadde vore sentralt både våren og hausten 1814. Var det med dette meint at oktroien skulle vere like uforanderleg som grunnlova? Det kunne i så fall henge saman med at under eineveldet blei ein oktroi som nemnt oppfatta som meir bindande enn vanleg lov.

I sluttføresegna kom utkastet tilbake til kor uforanderleg oktroien skulle vere. For dei 30 åra som den i utgangspunktet skulle vare, skulle banken "være forvisset om, at naar og saalænge den fyldestgjør sine Forpligtelser, skal ikke alene de Rettigheder, som den nu ere tilstaaede,

\footnotetext{
15 I Mestad 2010: 208-209 er det sagt at banken òg skulle ha einerett til å utgi Species-Mynt, men det er truleg ikkje riktig. Banken skulle etter $\S 2$ ha plikt til å ha eit «Forraad» av mynt og etter $\S 5$ bruke mynt som «skal være den samme [...] som den, der allerede forhen har været gangbar i Riget», men det er ikkje sagt at det skal vere ein einerett til utmynting.
} 
den ubrødeligen holdes”, jf. $\S 83$. Dette ville syte for at den private banken heldt seg strengt til si oppgåve: å halde oppe eit stabilt pengevesen.

Utkastet var i realiteten utarbeidd av grev Wedel-Jarlsberg, som på Eidsvoll blei oppnemnd som leiar av denne særskilde finanskomiteen, men som i 1815 var blitt finansminister i den norske regjeringa. ${ }^{16}$ Han var Noregs fremste adelsmann og stor godseigar, men utdanna jurist frå København, og hadde tidlegare jobba for finansminister grev Schimmelmann der. ${ }^{17}$ Dermed hadde han både teoretisk og praktisk bakgrunn for arbeidet. Utkastet er nesten ordlydande likt med oktroien for den dansk-norske Species-bank frå 16. februar 1791, bortsett frå omsynet til den nye norske forfatninga og til at det skulle opprettast bankavdelingar i ein del byar. ${ }^{18}$ Den dansk norske Species-banken, som gjekk over ende i statsbankerotten i 1813, var grev Wedel sjølvsagt godt kjend med frå København. ${ }^{19}$

Den rettslege bakgrunnen for oktroi-framlegget frå finanskomiteen må ein søkje i to linjer i dansk selskapsrett: ei linje frå handelsselskapa og ei frå dei to føregåande bankane, Speciesbanken og den tidlegare Kurantbanken. Organisatorisk hadde fleire av handelsselskapa sterke styringsorgan som tilsvarte eit representantskap, og i Den danske og norske Speciesbank frå 1791 var det eit sterkt representantskap med 15 medlemer fastsett i oktroien av $1791 \S 40 .{ }^{20}$ Under merkantilismen var oktroierte handelsselskap med monopolrettar, typisk handelsmonopol, ei sentral form for organisering av næringsverksemd. Dette kunne òg overførast til setelmonopol. I våre dagar, 200 år seinare, framstår slike monopolordningar som spesielt, men likevel nesten naturgitt når det gjeld setelmonopolet.

\section{Fundatsen frå 1816: Tvangsteikning av aksjar}

Det mest omfattande sakskomplekset på det første ordinære stortinget var ordninga av bankog pengevesen. ${ }^{21}$ Behandlinga blei svært innfløkt. Men når det gjaldt korleis ein skulle organisere setelbanken, var det kontinuitet frå innstillinga frå Wedels finanskomité. Lovvedtak om Noregs Bank skjedde 22. mai 1816, og lovene vart sanksjonert den 14. juni. ${ }^{22}$

\footnotetext{
${ }^{16}$ Yngvar Nielsen, Lensgreve Johan Caspar Herman Wedel Jarlsberg 1779-1840, bd. III 1815-1840, Christiania 1902: 27.

17 Sjå Mestad 2010: 209.

18 Nielsen 1902: 30.

${ }^{19}$ Om Speciesbanken, sjå òg Lie m.fl. 2016: 26-28.

${ }^{20}$ Mestad 2010: 209-211.

${ }^{21}$ Austnes 2016: 136.

22 Sjå Lie m.fl. 2016: 35-43 og Austnes 2016: 256-296. For ei eldre omfattande framstilling av bank- og finanssakene på dei første stortinga med tilvisingar, sjå Sverre Steen, På fallittens rand. Det frie Norge II, Oslo 1953: 47-50, 70-72, 100, 126 ff og 175-204.
} 
Sjølve opprettingsvedtaket må ein seie ligg i § 7 lov om pengevesenet, der det vart fastsett: «Der skal oprettes en ny Bank under Navn af Norges Bank, hvis Fond ei maa være under 2 Millioner og ei over 3 Millioner Speciedaler i Sølv." ${ }^{23}$ Framlegga både til oktroi og "Fundation" frå Stortingets tredje komité i innstilling av 13. april 1816, følgde opplegget og den same femdelte strukturen som framlegget frå finanskomiteen. Men lovteksten var meir gjennomarbeidd, og organiseringa fanst i eit frivillig og eit tvingande alternativ.

Lovvedtaket var såleis dobbelt: Ein Octroi i tilfelle grunnkapitalen til banken vart skaffa ved privat aksjeteikning, og ein Fundation i tilfelle grunnkapitalen vart skaffa gjennom innkreving av aksjekapital etter reglar for ein formuesskatt. ${ }^{24}$ Stortinget heldt altså fast ved omgrepet oktroi, men kva som presist var meint med dette, skal vi ikkje her ta standpunkt til fordi det siste alternativet vart den endelege løysinga etter ein runde med mislykka aksjeteikning. ${ }^{25}$ Denne formuesskatten, som var vanskeleg å drive inn, vart seinare heitande Sølvskatten. Men både politisk og i aksjeselskapsrettsleg samanheng er det viktig å merke at den ikkje gjekk inn i statskassa, men direkte inn i banken. Skattytarane fekk aksjar som vederlag for sine innbetalte «skattar». Dermed vart aksjeselskapet Noregs Bank grunnlagt med tvangsutskriven innbetaling av aksjekapital.

Organisatorisk var hovudskilnaden mellom den frivillige og den tvungne banken at den første skulle ha generalforsamling som valde representantskapet, og dette igjen skulle velje direksjon og administratorar ved filialane, medan i den tvungne banken var det Stortinget som skulle utnemne både representantskap, direktørar og administratorar, sjå begge utkast $\S$ 10. T. H. Aschehoug peikte seinare på at inntil banken eventuelt vart overlevert til aksjeeigarane "som en privat indretning", var det naturleg "at ansee Storthinget som Repræsentation for Actionærerne". Aschehougs resonnement var at dei som hadde røysterett ved stortingsval var i all hovudsak dei som betalte skatt, sjølv om røysteretten etter grunnlova ikkje formelt var knytta til skattytarposisjonen. ${ }^{26}$ Dermed kunne Stortinget innta ein svak

\footnotetext{
${ }^{23}$ Lov om Pængevæsenet av 14. juni 1816 § 7. I § 8 er det fastsett noko om subskripsjonen av fondet med fristar, og eventuelt om ein tvungen bank. Så står det at " $\varnothing$ vrige Bestemmelser om Bankindretningen indeholdes i en særskilt udfærdiget Octroi eller Fundation".

${ }^{24}$ Ein kan diskutere om det er tale om ei eller to lover, men det er iallfall gjort eit lovvedtak med tilvising til lov om pengevesenet av same dag $\S \S 7$ og 8. Vedtaket framstår som eitt lovvedtak, men i sjølve teksten står det at «saa foreskrives herved alternativ Lovene [altså i fleirtal] for bankens Bestyrelse ved følgende Octroi». Og etter oktroiteksten kjem «Fundation». Sitert etter Peter Vogt, Love, Anordninger, Kundgjørelser, aabne Breve,

Resolutioner m.m., der vedkomme Kongeriget Norges Lovgivning og offentlige Bestyrelse, 1ste Bind, indeholdende Aarene 1814, 1815 og 1816, Christiania 1817.

${ }^{25}$ Kva for grunnlovsvern privilega til aksjeselskapet Noregs Bank hadde når dei var gitt gjennom lovgiving, kjem vi tilbake til nedanfor.

${ }^{26}$ T. H. Aschehoug, Norges nuværende Statsforfatning, 2. utg., bd. II, Christiania 1892: 385.
} 
generalforsamlingsposisjon. Utbytet skulle nemleg avgjerast av representantskapet, ikkje av Stortinget. Og Stortinget skulle ikkje ha nokon instruksjonsrett over banken.

Stortinget slutta seg til komitéinnstillinga, som opna for at Stortinget etter at gjelda for innløysing av dei tidlegare riksbanksetlane var ordna, kunne avgjere å "overlade til de daværende Actieeiere at constituere sig til en aldeles privat Bank, med saadan Octroi, som derpaa er anvendelig". ${ }^{27}$ I praksis valde Stortinget aldri dette, slik at modellen for bank med tvangsinnskot stod ved lag heilt til banken vart oppheva som aksjeselskap i $1985 .^{28}$

Representantskapet skulle vedta rekneskapen, og "[n]aar Regnskabet saaledes er afgjort, skal Directionen foranstalte enhver Interessent udbetalt sin tilkommende Deel af den rene Fortjeneste" (Fundation § 56). Utbytet av drifta skulle såleis gå til aksjeeigarane (som på denne tida ofte blei omtalt som interessentar). Dette heng nær saman med det som var føresett om formålet med drifta i ei føresegn om direksjonen:

"Bankens Direction skal i det hele forestaae Banken, forvalte dens Midler, og sørge for alt det, hvorved dens Forretninger ordentlig kan fortsættes paa den i Octroien og Conventionen foreskrevne Maade til Interessentskabets Fordeel” $(\S 50) .{ }^{29}$

Ingenting er sagt om omsyn til det allmenne e.l. Det var selskapet, og dermed aksjeeigarane, som skulle bli tilgodesett. Denne formålsføresegna var felles for både det frivillige og det tvungne alternativet. At aksjekapitalen måtte tvangsutskrivast, endra ikkje på formålet med banken.

Banken fekk retten til å utgi setlar, og ved ei lovendring i 1818 einerett. Først i 1842 blei finansiell stabilitet oppnådd. Frå då av kunne banken innfri løftet om innveksling av setlar i pålydande sølvverdi. ${ }^{30}$ Myntretten blei derimot regulert i lov om pengevesenet $\S 5$, som fastsette at «Myntindretninger maa kun oprettes for Statskassens Regning». Det var vidareføring av det gamle myntregalet, altså kongens einerett til å slå mynt. ${ }^{31}$ Staten hadde altså myntretten og banken setelretten. Det stod ved lag heilt til 1962 då også myntretten blei

\footnotetext{
${ }^{27}$ Fundatsen $\S 73$.

${ }^{28}$ Om forslag om omdanning på Stortinget i 1818, sjå Nikolai Rygg, Norges Banks historie, Kristiania 1918: 154, og for ein generell gjennomgang av spørsmålet, innstillinga frå banklovkommisjonen av 1884, trykt som vedlegg til Oth. Prp. Nr. 8 (1888): Anhang IX s. 136-139.

${ }^{29}$ Den omtalte «Conventionen» var eit slags vedtekter som banken skulle gi seg sjølv.

${ }^{30}$ For den nyaste framstillinga, sjå Øyvind Eitrheim, Jan Tore Klovland og Lars Fredrik $\varnothing$ ksendal, A Monetary History of Norway, 1816-2016, Cambridge 2016: 83-95 og 109-112.

${ }^{31}$ Om myntregalet i Danmark-Noreg, sjå J. F. W. Schlegel, Danmarks og Hertugdømmenes Statsret med stadigt Hensyn til deres ældre Forfatning, Kiøbenhavn 1827: 339 og 362 ff.
} 
overført til banken. ${ }^{32}$ At dette kunne vere skilt, heng saman med at i første halvdel av 1800talet var det berre mynt som vart rekna som pengar, og setlar som gjeldsbrev («pengerepresentativ»). I det nye hundreåret har det ikkje skjedd rettslege, men store driftsmessige endringar. Den kongelige Mynt, altså myntfabrikken på Kongsberg, som banken hadde overtatt frå staten i 1962, blei seld av banken i 2001, og i 2007 opphøyrde seteltrykkinga i bankens eigen regi. Den blei utkontraktert. ${ }^{33}$

\section{Grunnlova § 110 som vern mot Sverige og mot myntunion}

Grunnlova $§ 110$ om bank- og pengevesen reiste gjennom den svensk-norske unionen ingen vanskar direkte i forhold til banken, men indirekte gjennom forholdet til den skandinaviske myntunionen. I 1873 forkasta Stortinget eit framlegg frå regjeringa om at Noreg skulle tiltre konvensjonen og dermed unionen, medan Danmark og Sverige samtykte. To år seinare slutta Stortinget seg likevel til, og dermed vart krone innført som mynteining i staden for spesiedalar. I debattane var det ulike argument mot. Eitt av dei var at ein myntunion ville vere i strid med grunnlova $§ 110$ som sa at Noreg skulle ha sitt eige bank- og pengevesen. ${ }^{34} \mathrm{I}$ stortingsdebatten hevda den leiande opposisjonsmann Johan Sverdrup at ein måtte både sjå på $\S 110$ og det vidare systemet i grunnlova: «Grundlovens $§ 110$ er aabenbart kun en Tilspidsen af, hvad der forøvrigt ligger i Grundloven, fremkalt ved det enkelte Tilfælde." Han heldt fram med at "Selvstændighed og Handlefrihed for os maa bevares". ${ }^{35}$ Andre talarar var endå klarare om $§ 110$. Representanten, lærar og bonde David Swensen, sa kort og godt at han ville røyste mot konvensjonen fordi "at vor Grundlovs $§ 110$ sættes ud af Virksomhed - ud af Betragtning kan man sige - for en lang Aarrække". ${ }^{36}$ Også representanten Ole Sivert Welde, han òg lærar og bonde, spurde om "skulle vi da som Nordmænd virkelig opgive Grundlovens $\S 110$ ”. Også andre viste til $\S 110$, men den varsame juristen Sverdrup sa seinare i debatten at han ikkje ville konkludere på om ein gjekk § 110 for nær, "men jeg siger, man gaar Aanden, om ikke Bogstaven i Grundloven for nær. ... naar svensk og dansk mynt har Tvangskurs hos os, da existerer der virkelig Fællesskab i Myntforholdene". ${ }^{37}$

\footnotetext{
32 Sjå NOU 1983:39 Lov om Norges Bank og pengevesenet: 83 og 106, og Per Christiansen, Norsk pengerett, Oslo 1987: 204-205.

33 Lie m.fl. 2016: 443.

34 Inngåande om myntunionen, Lie m.fl. 2016: 121-128, § 110 nemnt s. 124 note 45.

35 S.Tid. (1873): 587.

${ }^{36}$ S.Tid. (1873): 604.

37 S.Tid. (1873): 639.
} 
I 1875 blei myntunionen altså likevel vedtatt, men mot Sverdrups stemme. Og den varte til den braut saman i 1914. Formelt blei konvensjonen likevel først sagt opp i 1972. ${ }^{38}$

Regelen om banken og pengevesenet i $§ 110$ blei oppheva i 1911, som del av oppryddinga i grunnlova etter unionsoppløysinga. Grunngivinga var knapp: «§ $110 \ldots$ fastslaar Norges ret til sin egen bank og sit eget pengevæsen og antages derfor overflødig efter unionens opløsning». ${ }^{39}$

\section{Staten og aksjeeigarane fram til 1949}

I Noregs Banks rettslege historie var det særleg gjennom 1800-talet eit gjennomgåande tema kor langt Stortinget ved lovgiving om banken kunne gå i å omforme banken og dermed omdanne eller innskrenke bankens rettar slik dei kom til uttrykk i fundatsen av 1816. Slike endringar ville lett påverke situasjonen for aksjeeigarane både positivt og potensielt negativt. Rettsleg gjaldt spørsmåla forholdet mellom privileg gitt av lovgivar i fundatsen og forbodet mot tilbakeverkande lovgiving i grunnlova $§ 97$, men òg forholdet til regelen i grunnlova $\S$ 105 om ekspropriasjon og erstatning..$^{40}$

Reelt var dette spørsmål om utrekninga av overskot og fordelinga av utbytet frå bankdrifta. I 1816 var det klart at aksjeeigarane skulle ha heile utbytet når det måtte kome i framtida. Men etter kvart som banken blei tillagt andre og utvida oppgåver gjennom fleire endringslover som var med å generere overskot, var det for både storting og regjering klart at det auka overskotet ikkje berre skulle gå til dei private eigarane. Om prinsippet om at dei opphavlege privilega sette grenser for kva staten kunne krevje, synest det å ha vore semje. Men den nærmare fordelinga vekte strid. Utbytet til aksjonærane var godt i andre halvdel av 1800talet. I dei 25 åra 1855-1879 var det berre to gonger under 10 prosent, og for heile perioden 1855-188510 prosent i snitt. ${ }^{41}$ Skulle aksjeeigarane også ha særleg oppside ut over dette? Slik ville det vere etter vanlege aksjeselskapsrettslege reglar.

Spørsmålet om retten til avkastninga av verksemda kom på spissen i lovarbeidet fram til 1892-lova. Finansminister Helliesen hadde meint at fordelinga av overskot mellom utbyte til

\footnotetext{
38 NOU 1983:39 Lov om Norges Bank og pengevesenet: 84.

39 St.prp. nr. 102 1905-1906: 5 og 12.

${ }^{40} \mathrm{Om}$ utviklinga av banken fram mot vår tid med vekt på andre rettslege spørsmål, særleg om kompetanseforholdet til regjeringa og andre styresmakter, sjå Carsten Smith, Bankrett og statsstyre, Oslo 1980: 62-125 og 160-220.

${ }^{41}$ Henrik Helliesen, Nogle kritiske bemærkninger ved den under 6te decbr. 1884 anordnede bankkommissions indstilling, Statsøkonomisk tidsskrift, 1888: 1-59 på s. 35-36.
} 
aksjeeigarane (inkludert staten som aksjeeigar) og til staten direkte skulle avtalast mellom banken og staten for kvart år. ${ }^{42}$ I følgje Helliesen var det umogeleg på førehand å fastleggje ei fordeling som avspegla avkastninga av det opphavlege privileget - som skulle gå til aksjeeigarane - og avkastninga av dei tilleggsrettane som banken hadde fått gjennom ulike lover, og der avkastninga i hovudsak skulle gå til staten.

Proposisjonen frå Helliesen blei ikkje behandla. Selmer-ministeriet blei i staden dømt i Riksretten i 1884, og etter eit mellomspel overtok Venstre-regjeringa til Johan Sverdrup. Den utnemnde ein bankkommisjon under leiing av den relativt radikale venstremannen Johannes Steen, som seinare vart stats- og finansminister. 1892-lova blei vedtatt under Steens første regjering då Steen samstundes var finansminister. Kommisjonsinnstillinga avgitt i september 1886 var prega av at aksjeeigarane ikkje burde få for mykje utbyte av drifta av Noregs Bank.

Innstillinga blei sterkt kritisert frå juridisk så vel som økonomisk perspektiv av nettopp tidlegare finansminister Helliesen. Det sentrale i den juridiske kritikken var at staten ikkje gjennom lovgiving kunne ta frå banken og dermed aksjeeigarane dei rettane som følgde av privilega frå 1816. Dette bygde Helliesen til dels på grunnlova $§ 97$ om forbod mot tilbakeverkande lovgiving og til dels på § 105 om vern mot ekspropriasjon utan erstatning. Helliesen både analyserte fundatsen og gjekk gjennom heile historikken til det økonomiske forholdet mellom staten og banken fram til tidspunktet for kommisjonsinnstillinga. Han gjekk òg konkret inn på dei føresetnadene kommisjonen hadde gjort som grunnlag for fordeling av overskot mellom banken og staten. ${ }^{43}$

I lovproposisjonen blei kommisjonens oppfatning av forholdet mellom staten og banken omtalt slik at «Fundatsen indeholder som Bankens Grundlov det Banken tilsikrede Privilegium, hvori der ikke uden Erstaning kan gjøres Skaar». ${ }^{44}$ Privileget blei sagt å vere setelutgivingsretten mot det innskotne fondet (då tilsvarande 8 millionar kroner) og at setlane var tvingande betalingsmiddel (fundatsen $\S \S 4 \mathrm{og} 7$ ). Om prinsippet var det altså semje mellom venstre- og høgresida.

Kommisjonen framheva viktig nok at banken ikkje var, og heller ikkje skulle bli, ein «Statsinstitution, men en selvstændig, Aktieeierne tilhørende Indretning, over hvis Interesser

\footnotetext{
42 Punkt 8 hos Helliesen 1888: 3.

${ }^{43}$ Dette er hovudpoenget i Helliesen 1888. Sjå grunnlovstilvisingar s. 14, 24, 27 («konfiskation»), 28.

${ }^{44}$ Oth. Prp. Nr. 8 (1888): 2. Denne proposisjonen inneheld hovudteksten som kommenterer lovforslaget, men formelt blei lova vedtatt på grunnlag av Oth. Prp. No. 9 (1892), sjå om forholdet mellom dei, Indst. O. II. (1892): 1-2.
} 
Lovgivningen ikke mere end over andre lignende Indretninger kan disponere til Fordel for Statskassen». ${ }^{45}$

Proposisjonen uttalte òg at staten hadde rådvelde over banklovgivinga når den berre ikkje «uden Erstatning indskrænker, hvad der ansees for Bankens fundamentale Rettigheder». Det var retten til å utgi pengesetlar for ein viss sum, at setlane var tvingande betalingsmiddel, at bankens fond berre skulle brukast til innløysing av setlar og skattefritaket. Departementet meinte denne oppfatninga «formentlig» fall saman med kommisjonens oppfatning av forholdet mellom staten og banken. ${ }^{46}$ Dette blei sagt i samanheng med at direksjonen i banken hadde peikt på at lovforslaget frå kommisjonen ikkje uttrykte den «kontraktmæssige Natur» ved «de Banken ved Fundatsen positiv [!] tillagte Rettigheder». Grensa mellom «Bankens fundamentale Love eller, om man saa vil udtrykke sig, mellem dens Grundlove og de øvrige Bestemmelser Banken vedkommende», ville kunne kome til å bli utviska dersom ein vedtok forslaget, hevda direksjonen. ${ }^{47}$ Ein ser korleis språkbruken framleis omtaler grunnføresegnene for banken som grunnlover. På dette tidspunktet var medlemene av bankdireksjonen, som regjeringa, venstremenn. ${ }^{48}$ Også venstremennene i direksjonen ønskte såleis ei klar lovregulering av at banken hadde særlege privileg som lovgivar ikkje kunne ta frå den. Men venstreregjeringa følgde ikkje dette opp. Den respekterte likevel prinsippet om at aksjeeigarane hadde rettar som staten ikkje kunne ta frå dei utan erstatning. Usemja i samtida gjekk på korleis ein skulle gjennomføre dette.

I proposisjonen skreiv departementet under overskrifta om rekneskap og utbyte at det «vigtigste Spørgsmaal, som herunder frembyder sig, er Udbyttets fordeling mellem Banken og Staten». ${ }^{49}$ Departementet valde å gå noko kortare i å gi staten del i utbytet enn kommisjonen hadde føreslått. Ei forlodds overføring til staten på 350000 kr årleg utan omsyn til resultatet av drifta, blei ikkje føreslått i proposisjonen. Dette framlegget hadde blitt kritisert både av bankdireksjonen og av Helliesen. ${ }^{50}$

I 1892-lova blei det vedtatt følgjande fordelingsregel, etter at det hadde vore politisk usemje om aksjeeigarane skulle forlodds ha 6 eller 8 prosent: Etter dekning av kostnader og

\footnotetext{
${ }^{45}$ Sitert etter Oth. Prp. Nr. 8 (1888): 3.

${ }^{46}$ Oth. Prp. Nr. 8 (1888): 6, og likeeins T. H. Aschehoug, Norges nuværende Statsforfatning, 2. utg., bd. III, Christiania 1893: 277.

47 Oth. Prp. Nr. 8 (1888): 5.

${ }^{48}$ Lie m.fl. 2006: 142.

${ }^{49}$ Oth. Prp. Nr. 8 (1888): 38.

${ }^{50}$ Oth. Prp. Nr. 8 (1888): 45 og Helliesen 1888: 34-35.
} 
avsetningar for tap skulle aksjeeigarane først ha «6 pCt. af Aktiernes Paalydende», deretter skulle ei avsetning gjerast til reservefondet med inntil 10 prosent av det som var igjen av overskotet, før det gjenverande skulle delast 50/50 mellom aksjeeigarane og staten til aksjeeigarane hadde fått 10 prosent utbyte. Ut over dette igjen skulle staten ha $3 / 4 \mathrm{og}$ aksjeeigarane $1 / 4$. I tillegg var det ein tryggingsregel for aksjeeigarane. Dersom dei ikkje fekk 6 prosent utbyte, skulle dei få dekning frå reservefondet så lenge fondet ikkje gjekk under 4 millionar kroner. ${ }^{51}$ Det underliggjande prinsippet i dette var at utbytet skulle liggje omtrent der det hadde lege i dei seinare åra, altså rundt 10 prosent. ${ }^{52}$ Ulikt vanlege aksjeselskap ville ein særleg inntektsauke altså ikkje gi mykje meir til aksjeeigarane. I den nye bankhistoria til Lie m.fl. blir reglane om fordelinga omtalt som «endret og gjort ryddige». I samtida omtalte professor Aschehoug dei som «temmelig vilkaarlige». ${ }^{53}$ Etter at lova var vedtatt, skreiv Aschehoug eit stort avsnitt i læreboka om det grunnlovsmessige vernet for privilega til banken. ${ }^{54}$ Dette var eit element i Aschehougs mykje meir omfattande behandling av verknaden av $§ 97$ og styrkinga av det vernet som føresegna skulle gi, enn det som hadde vore oppfatninga i tidlegare norsk statsrettsteori.

I den nye bankhistoria blir òg det at banken er eit hovudsakleg privateigd aksjeselskap framheva av Einar Lie i ein svært viktig samanheng, nemleg ved tolkinga av åtferda til banken under leiarskap av Nicolai Rygg ved bankkrisa i 1920-åra og i 1932 og ved gjenetablering av gullinnløysinga, som hadde vore suspendert sidan 1914. Det var ein «viktig realitet», skriv Lie, etter mitt syn med rette, at «Norges Bank var et aksjeselskap med mange private eiere som skulle ha sin avkastning, og var slik sett ikke en del av statsapparatet». Det blei i perioden, framhevar han, skilt systematisk mellom «statsmyndighetene» på den eine sida og aksjeselskapet Noregs Bank. ${ }^{55}$ Dette er ei anna tolking enn Francis Sejersteds, som la meir vekt på at åtferda til Rygg måtte forklarast ved at han oppfatta seg som rettsstatleg bunden..$^{56}$

\footnotetext{
${ }^{51} \S 40$ i 1892-lova. Og endå var det nokre justeringsdetaljar i forholdet mellom staten og aksjeeigarane.

52 Oth. Prp. Nr. 8 (1888): 40 og 45.

53 Lie m.fl. 2016: 146 og Aschehoug 1893: 276.

${ }^{54}$ Aschehoug 1893 s. 272-278, jf. T. H. Aschehoug, Norges nuværende Statsforfatning, 2. utg., bd. II, Christiania 1892: 186-187 der Aschehoug gjer gjeldande at eit privileg òg kan tildelast gjennom lovgiving, altså det som var tilfellet med banken; privileget trong ikkje byggje på ein kontrakt mellom staten og ein privat part. 55 Lie m.fl. 2016: 475-476, jf. s. 477 og 263-265.

${ }^{56}$ Sjå Francis Sejersted, Ideal, teori og virkelighet. Nicolai Rygg og pengepolitikken i 1920-årene, Oslo 1973. For ein annan kritikk av rettsstatssynspunktet hos Sejersted, sjå Smith 1980: 102-103.
} 
Rygg hadde tatt juridisk embetseksamen i 1894, året etter at den siterte andre utgåva av Aschehougs lærebok kom ut. Viktigare var nok at Rygg, like før han blei utnemnd i 1920, hadde gitt ut første band av historia til Noregs Bank. ${ }^{57}$ Han kjende bankhistoria og grunnlagsdokumenta betre enn nokon annan. Både studiet av den og ikkje minst av forarbeida til 1892-lova ville kunne byggje sterkt oppunder eit slikt syn hos Rygg, slik ein kan sjå av sitata ovanfor. Rygg viste også i debattar uttrykkjeleg til den, etter hans syn uheldige, røynsla frå den langsame etableringa av sølvinnveksling fram til $1842 .{ }^{58}$

Det var elles også 1892-lova som innførte at leiarstillinga i banken, altså den stillinga Rygg sat i, var ei heiltidsstilling, som formann i direksjonen, og at han skulle utnemnast av regjeringa, ikkje av Stortinget eller representantskapet.

Eit aksjeselskapsrettsleg spørsmål som også kom opp i førebuinga til det som blei 1892-lova, var kva for rolle aksjeeigarane burde spele i banken ut over å ta imot utbyte. Eit aksjeselskap der aksjeeigarane var utan organisatoriske rettar, var ein anomali og berre grunngitt $i$ at frivillig oppretting av banken ikkje vart nådd i 1816. Som omtalt la finansminister Henrik Helliesen fram ein proposisjon om endringslov i $1882 .{ }^{59}$ Regjeringa føreslo der at det skulle opprettast generalforsamling i banken. I den skulle aksjeeigarane velje seks av i alt femten medlemer av det dominerande selskapsorganet representantskapet, regjeringa skulle utpeike tre og Stortinget dei resterande seks. Dette ville altså styrke, og dermed gå i retning av å normalisere, rolla for aksjeeigarane. Forslaget, som Helliesen i ettertid sa var meint som ei «hovedforandring», blei sagt å springe ut av ei innstilling frå «et større antal aktieeiere». ${ }^{60} \mathrm{Jan}$ Thomas Kobberrød peiker på at forslaget ikkje berre ville styrkje aksjeeigarane, men samstundes ville gi dei store aksjeeigarane og regjeringa fleirtal i representantskapet mot dei seks stortingsvalde, samstundes som tanken i proposisjonen var å leggje meir oppgåver til representantskapet. Slik kan ein sjå forslaget som ei mobilisering mot den framveksande venstresida i Stortinget som etter fundatsen oppnemnde alle dei femten medlemene. ${ }^{61}$ Lovforslaget vart ikkje realitetsbehandla i Stortinget. Dette må ha vore siste gongen det blei gjort forsøk på å styrkje stoda for aksjeeigarane i Noregs Bank ut over dei økonomiske rettane.

\footnotetext{
${ }^{57}$ Nicolai Rygg, Norges Banks historie. Del 1. 1816-1850, Oslo 1918.

${ }^{58}$ Sjå Einar Lie, Norsk økonomisk politikk etter 1905, Oslo 2012: 48 og Eitrheim m.fl. 2016: 330.

${ }^{59}$ Sjå Lie m.fl. 2016: 141, og for ein gjennomgang av hovudpunkta i proposisjonen, Helliesen 1888: 1-3.

60 Helliesen 1888: 3.

${ }^{61}$ Lie m.fl. 2016: 141.
} 


\section{Avvikling av dei private aksjeeigarane og deretter aksjeselskapet}

Etter den andre verdskrigen, i den planøkonomiske perioden med rein Arbeidarpartiregjering, vart det private aksjeeigarskapet i banken oppheva. Ved lov 8. juli 1949 nr. 15 overtok staten alle private aksjar i Noregs Bank. Men banken heldt fram som aksjeselskap.

På dette tidspunktet var aksjekapitalen 35 millionar kroner. Av dette hadde staten og offentlege fond 6 millionar, berre om lag 17 prosent. ${ }^{62}$ Gjennomgåande hadde bankaksjane gitt svært god avkastning. Årleg utbyte i perioden 1923-1939 var 8 prosent. Sidan 1940 hadde det vore 6 prosent. I tidlegare periodar hadde det som nemnt vore endå høgare. Innløysingskursen i 1949 vart fastsett i lova til 180 prosent av pålydande basert på ei vurdering i høve til oreigningsvernet i grunnlova $§ 105$. Dette blei godtatt av aksjeeigarane.

I den same proposisjonen var det òg eit framlegg som direkte gjekk på forholdet mellom Stortinget og regjeringa. Banken skulle heretter oversende årsmelding og rekneskap til departementet "for å forelegges Kongen og meddeles Stortinget”. Tidlegare gjekk meldinga rett til Stortinget. Framlegget vart av opposisjonen på Stortinget oppfatta som eit åtak på det gamle prinsippet om at Noregs Bank var "Stortingets bank". ${ }^{63}$ Opposisjonen meinte dette var eit brot på det "demokratiske prinsipp" som var uttrykt i grunnlova $§ 75 \mathrm{c} \mathrm{om}$ at Stortinget fører oppsynet med pengevesenet. Framlegget "danner et vesentlig ledd i Regjeringens bestrebelser på å sentralisere kontrollen over vårt økonomiske liv i strid med det demokratiske grunnsyn som Stortingets myndighet er uttrykk for”. Protesten var forgjeves.

Trettiseks år seinare vart aksjeselskapsforma fjerna. I den nye generelle reformlova for banken, sentralbanklova av $1985,{ }^{64}$ vart det i $§ 33$ andre ledd fastsett at aksjane i banken skulle bli utløyst etter nærare reglar fastsett av Kongen. Det var formelt det endelege oppgjeret etter Sølvskatten. Framstegspartiet - og banken sjølv - gjekk gjekk mot dette. Banken uttalte at det var uklart kva som var meint å liggje i framlegget frå Ryssdal-utvalet, og viste m.a. til at spørsmålet om søksmålskompetanse, altså om staten eller banken ville vere rett part i ei rettssak, berre var løyst i forarbeida, ikkje i lovteksten. ${ }^{65}$ Dette var mindre vesentleg argumentasjon. Underliggjande var vel poenget at aksjeselskapsforma tydelegare demonstrerte ei uavhengig stilling for banken. Dei andre partia følgde proposisjonen, ikkje

\footnotetext{
62 Ot.prp. nr. 65 (1949): 1.

63 Innst. O. XI 1949: 5.

${ }^{64}$ Lov nr. 28/1985.

${ }^{65}$ For bankens syn, sjå Ot.prp. nr. 25 (1984-85): 19.
} 
banken, og vedtok å oppheve aksjeselskapsforma. For Framstegspartiet var synspunktet del av eit utvida resonnement om å sikre eller auke maktfordelinga i det norske samfunnet, og å etablere skrankar for kva regjeringa kunne gjere. Stortingsrepresentanten frå Framstegspartiet, Carl I. Hagen, ville at banken skulle vere sjølvstendig og "forpliktet av en spesiell hovedoppgave, nemlig å verne pengeverdien". ${ }^{66}$ Dette var godt i tråd med intensjonane bak det å etablere banken som aksjeselskap i 1816.

\section{Regjeringskontroll med banken og grunnlova $§ 19$}

Grunnlova $§ 19$ har stått uendra sidan 1814 , men tolkinga har skifta. Eit sentralt spørsmål er om den gir regjeringa ein verna rett, eit prerogativ, til å forvalte statseigedom. Så lenge banken var eit heilt eller delvis privateigd aksjeselskap, var spørsmålet ikkje aktuelt. Men i lovarbeidet fram til sentralbanklova i 1985 kom det opp.

Ved sentralbanklova blei kompetansen til å oppnemne det som no skulle heite hovudstyret $\mathrm{i}$ banken lagt berre til kongen. Tidlegare var regelen at kongen oppnemnde formann og nestformann (sentralbanksjef og visesentralbanksjef), og Stortinget dei andre tre deltidsmedlemene. ${ }^{67}$ Endringa var i tråd med framlegget frå Ryssdal-utvalet, og proposisjonen viste til grunngivinga i utgreiinga. ${ }^{68}$ Det blei òg vedtatt ein særleg instruksjonsregel, som vi kjem tilbake til nedanfor.

Grunngivinga hos Ryssdal-utvalet ser til dels nettopp ut til å ha vore omsynet til regelen om forvaltning av statseigedom i grunnlova $\S 19$. Det som i proposisjonen blir sitert frå utgreiinga er m.a. følgjande:

«Norges Banks forvaltningsmessige oppgaver tilsier ikke at den med hensyn til oppnevning av hovedstyret står i noen særstilling. Kongen er høyeste utøvende myndighet i penge-, kreditt- og valutapolitikken. Det er regjeringen som har det konstitusjonelle og parlamentariske ansvar for at politikken utformes i samsvar med Stortingets $\emptyset$ nske. Norges Bank er i denne sammenheng et utøvende og rådgivende organ for regjeringen. Den særlige vekt utvalget har lagt på bankens rådgivningsfunksjon, peker også i retning av Kongen bør oppnevne hovedstyret.»

\footnotetext{
66 Innst. O. nr. 50 (1984-85): 7-8, sitatet s. 8, utheving i originalen.

${ }^{67}$ NOU 1983:39: 336.

68 Ot.prp. nr. 25 1984-85: 73 med tilvising til NOU'en s. 338, jf. proposisjonen s. 77, utan eg kan sjå at departementet seier noko særleg om grunngivinga.
} 
Dette blei òg grunngitt med at samla oppnemning ville gjere det «lettere å få en allsidig og godt koordinert sammensetning av styret i relasjon til de saker det skal avgjøre».

Departementet siterte ikkje vidare frå grunngivinga, men Ryssdal-utvalet synest å ha vore opptatt av grunnlova $\S 19$. Før det siterte avsnittet hadde utvalet brukt nesten ei heil side på å sitere frå det Ingvaldsen-utvalet hadde sagt om grunnlova $§ 19$ i det viktige St.dok. nr. 7 (1972-73). ${ }^{69}$ Innstillinga frå Ingvaldsen-utvalet var ein sluttstein i utgreiingsarbeidet om forholdet mellom regjeringa og statsbedriftene som tok til etter Kings Bay-ulykka i 1961. Det som m.a. blir sitert av Ryssdal-utvalet er at $\S 19$ i grunnlova «er blitt oppfattet slik at dersom forvaltningen av statseiendom legges til et særskilt organ, kan ikke Stortinget velge medlemmer av organet, eller i hvert fall ikke flertallet av medlemmene.» ${ }^{70}$ Dersom Noregs Bank var omfatta av regelen, ville dette gått direkte imot ordninga i banken. Men Ingvaldsenutvalet viste også til at det var ei viss usemje om rekkjevidda av $§ 19$ og gjennomførte ei vurdering av om styret for statsbankane, som var det utvalet vurderte på det punktet, burde oppnemnast av regjeringa «uavhengig av spørsmålet om hva $\S 19$ her tillater». ${ }^{71} \mathrm{Og}$ då meinte Ingvaldsen-utvalet at regjeringa burde ha heile oppnemningsretten. Det burde òg gjelde for «andre forvaltningsorganer når Regjeringen har instruksjons- og kontrollmyndighet og dermed et Øverste ansvar for virksomheten». Konklusjonen var då: «Den generelle regel når det gjelder kollegiale organer med avgjøringsmyndighet bør derfor være at valgretten ligger hos forvaltningen.» Dette hadde også utanriks- og konstitusjonskomiteen sagt seg einig i, blir det sitert. ${ }^{72}$ Ryssdal-utvalet sa deretter det som er sitert ovanfor om at Noregs Bank ikkje stod i noka særstilling. ${ }^{73}$

For meg er det på grunnlag av teksten i utgreiinga litt uklart om Ryssdal-utvalet med dette la til grunn at resultatet følgde av ei tolking av $\S 19$ eller av den meir generelle vurderinga av kva som var tenleg, som Ingvaldsen-utvalet gjorde. Carsten Smith, som hadde vore medlem av Ryssdal-utvalet, skreiv likevel etterpå at grunngivinga for å leggje oppnemningsretten til regjeringa «er i første rekke det prinsipp som grunnlovens § 19 bygger på. At forvaltningen av statens eiendom skal ligge hos regjeringen». Så viste han til at når «staten siden 1949 er blitt eier av Norges Bank, er det best i samsvar med denne [altså § 19] at regjeringen

\footnotetext{
69 Utredning fra Utvalget til å utrede spørsmål vedrørende Stortingets kontroll med forvaltningen m.v. Også trykt som NOU 1972:28.

${ }^{70}$ Sitert i NOU 1983:39: 337 med tilvising til Ingvaldsen-utvalet s. 38.

${ }^{71}$ Noregs Bank var ikkje omfatta av det tradisjonelle omgrepet statsbankane.

72 S.st.

${ }^{73}$ NOU 1983:39: 338.
} 
oppnevner hovedstyret». ${ }^{74}$ Dette underbyggjer at utvalet bygde på $§ 19$ fordi Smith tidlegare hadde hevda at Noregs Bank ut frå «statspraksis» ikkje var omfatta av grunnlova § 19. Det hadde han grunngitt med at fordi praksis frå tida før staten overtok alle aksjane var blitt ført vidare utan kommentar etter 1949, måtte banken falle utanfor § 19. I læreboka Bankrett og statsstyre frå 1980 hadde Smith konkludert med at «grunnloven ikke sier noe om Norges Banks rettsstilling eller legger bindinger på lovgivers frihet». ${ }^{75}$ Det var dermed eit punkt som Smith ville vere særleg merksam på i utgreiingsarbeidet.

Spørsmålet i dag er dermed om grunnlova $§ 19$ hindrar at banken som statseigedom blir gjort for sjølvstendig. Ein ting er oppnemning av hovudstyre, ein annan er om banken skal bli meir uavhengig av instruksjonsrett frå regjeringa. Dette kjem vi tilbake til nedanfor.

Det er påfallande at den norske lova av 1985 gjorde banken mindre uavhengig av regjeringa samstundes med at ein internasjonalt igjen hadde byrja å drøfte om sentralbankar burde vere meir uavhengige. ${ }^{76}$ Men den nasjonale konteksten med oppfatninga av grunnlova $§ 19$ kan forklare dette utfallet.

\section{Noregs Bank inn igjen i grunnlova i 2016}

I mai 2016 kom Noregs Bank inn igjen i grunnlova. Stortinget vedtok 24. mai ein ny § 33, som lyder slik i bokmålsversjonen: «Norges Bank er landets sentralbank.» Ordlyden er, litt forbausande, identisk med $\S 1$ første ledd første punktum i sentralbanklova av 1985.

Den nye grunnlovsføresegna vil først og fremst ha symbolverknad, men òg tene eit pedagogisk formål. Spørsmålet om regulering av banken fall utanfor mandatet for Lønningutvalet som skreiv utkastet til den store grunnlovsrevisjonen i 2014, men spørsmålet blei likevel sett i samanheng med denne. Den nye paragrafen blei vedtatt med 158 mot 8 røyster i

\footnotetext{
${ }^{74}$ Carsten Smith, Ny lov om Norges Bank og pengevesenet, Jussens Venner 1985: 20-35 på s. 23. Også trykt i Carsten Smith, Loven og livet, Oslo 1996: 289-306. Sitatet på s. 293. Helge Syrstad les forarbeida og Carsten Smith litt annleis, sjå kompressavsnittet hos Helge Syrstad, Sentralbankens uavhengighet, 2004: 200. Han meiner det er «utvilsomt» at grunnlova § 19 ikkje omfattar Noregs Bank. Dette er ikkje særleg utdjupa ut over ein merknad om at «det fremgår at verken Ryssdalutvalget eller C. Smith anså at gr. § 19 dermed skulle få anvendelse for Norges Bank». Sjå likevel Syrstads korte diskusjon s. 201 der han går litt nærmare inn på § 19 med utgangspunkt i at Smith synest å meine at Noregs Bank etter ei «ordinær» forståing av grunnlova § 19 skulle ha vore omfatta av føresegna, men Syrstad held fast ved at løysinga etter gjeldande rett «er klar». Syrstads poeng er m.a. at § 19 særleg tar sikte på forvaltning av «eiendommer, ikke politikk». Realiteten i dette er i alle fall mindre treffande no når forvaltning av Statens pensjonsfond utland, som er investert i aksjar, obligasjonar og fast eigedom, er ein stor del av verksemda i banken.

75 Sjå Smith 1980: 179.

${ }^{76}$ Sjå t.d. Syrstad 2004: 78-80, som også peikar på at sentralbanksjef Hermod Skånland viste til dei nye trendane i tenkinga omkring sentralbankar i sin samtidige kritikk av Ryssdal-utvalet, sjå Syrstad på s. 80.
} 
Stortinget. ${ }^{77}$ Berre Venstre røysta mot. Representanten Abid Raja grunngav det i komitéinnstillinga med eit tilsynelatande prinsipielt standpunkt, at Venstre var «imot å ta inn selvfølgeligheter og tillegg som ikke har noen reell betydning i Grunnloven». ${ }^{78}$

Til dette sa Jette Christensen frå Arbeidarpartiet i debatten at ho ville minne om at då Stortinget «gikk gjennom grunnlovsrevisjonen opp mot jubileet i 2014, var noe av poenget å oppgradere Grunnloven og ta inn flere menneskerettigheter, men også at man skulle gi et klarere bilde av hvordan Norge ser ut, hvordan Norge styres, og hvilke store institusjoner Norge består av». Ho oppfatta forslaget om å grunnlovfeste Noregs Bank som ledd i dette. ${ }^{79}$

Vedtaket var godt førebudd etter initiativ frå dåverande statssekretær for Senterpartiet i Finansdepartementet, Morten Søberg, og med utgreiingar både frå ein juss- og ein økonomiprofessor. ${ }^{80}$ Forarbeida gir ingen indikasjonar på at verknaden av vedtaket er meint å vere meir enn pedagogisk. I grunngivinga vart det m.a. sagt at meininga med «ei stutt og stadfestande grunnlovfesting er å tydeleggjera at banken er ein hjørnestein i den norske statsskipnaden». Og det blei sagt at framlegget var nøytralt med omsyn til norsk EUmedlemskap..$^{81}$

Det er ein god tanke at grunnlova skal spegle statsskipnaden i hovudtrekk. Og sentralbankfunksjonen er sentral i moderne statar. Den er del av den reelle maktfordelinga. Men ein kan lure på om det jamvel låg fleire tankar under for nokon. Den tidlegare bankføresegna i grunnlova var eit vern mot integrasjon i unionen med Sverige. Som nemnt ovanfor hevda Johan Sverdrup i stortingsdebatten om nordisk myntunion i 1873 at $§ 110$ var del av grunntanken i grunnlova om at "Selvstændighed og Handlefrihed for os maa bevares". 82

Kan det vere slik at nokon av dei som stod bak forslaget såg at den nye paragrafen òg kunne vere til hjelp i ein komande EU-kamp? Senterpartiet hadde i Stortinget våren 2016 også oppe eit anna grunnlovsforslag, som fall same dagen som bankføresegna vart vedtatt. Det lydde:

\footnotetext{
77 S.tid. (2016): 3294.

78 Innst. 272 S (2015-2016): 3.

${ }^{79}$ S.tid. (2016): 3287.

${ }^{80}$ Utgreiingane frå Eivind Smith og Aanund Hylland er trykt som vedlegg til Dokument 12:29 (2011-2012). Sjå òg Eivind Smith, Sentralbanken som uavhengig myndighet under konstitusjonen?, i Allmänt och enskilt offentlig rätt i omvandling. Festskrift till Lena Marcusson, Stockholm 2013: 337-347, der han m.a. samanliknar med den svenske grunnlova, Regjeringsformen 9. kapittel § 13, der det heiter: «Riksbanken är rikets centralbank».

${ }^{81}$ Dokument 12:29 (2011-2012): 159.

82 S.Tid. 1873: 587.
} 
«Den norske pengeeininga er ei krone. Krona er delt i hundre øre.» Dette var iallfall tenkt som vern mot eventuell deltaking i eurosamarbeidet i EU, og fekk berre dei ni røystene frå Senterpartiet. ${ }^{83}$

Ein reell verknad av den nye føresegna kan vere at den legg visse avgrensingar på seinare lovgiving om Noregs Bank. Som nemnt er reguleringa i sentralbanklova basert på eit omgrep om ein sentralbank. Dersom lovgivar skulle ønskje å endre funksjonsområdet for Noregs Bank, kan det hende at dette omgrepet set visse grenser. Då banken blei oppretta i 1816, var den ikkje ein sentralbank slik ein forstår omgrepet, som er nyare. Først frå rundt 1880 var det vanleg å tale om banken som ein sentralbank, og lovfesting av omgrepet skjedde først med sentralbanklova i $1985 .{ }^{84}$ Ein annan tenkjeleg verknad, som ikkje er omtalt, kan vere at sentralbankomgrepet kan seiast å innebere eit visst krav om uavhengig stilling, og at den derfor kan brukast som argument mot at regjeringa må ha rett til å instruere i medhald av grunnlova $§ 19$, som er omtalt ovanfor.

\section{Ny lovgiving om banken?}

No vil det nok kome ei ny sentralbanklov, eller iallfall lovendringar. Eit utval, leia av tidlegare sentralbanksjef og finansråd Svein Gjedrem, vart oppnemnd i april 2015 og skal gi si innstilling i juni 2017. ${ }^{85}$ I mandatet heiter det at utvalet skal «gjennomgå sentralbankloven i lys av de store endringene som har funnet sted i bankens oppgaver». Sentralt her vil nok vere forvaltninga av Statens pensjonsfond utland, som ligg til banken. ${ }^{86}$ I 2012 passerte talet på tilsette i banken som forvaltar Statens pensjonsfond utland, talet på tilsette som driv heile sentralbankverksemda. ${ }^{87}$ Vidare heiter det at utvalet skal «vurdere styringsstrukturen for

\footnotetext{
${ }^{83}$ Sjå S. tid. (2016): 3294, jf. debatten s. 3285-3286.

84 । 1899 blei det påfallande nok derimot etablert ein forretningsbank med namnet Centralbanken for Norge, sjå Lie m.fl. 2016: 143. Men t.d. Helliesen 1888 bruker sentralbankomgrepet.

85 Under korrekturen til denne artikkelen blei innstillinga på over 500 sider avgitt den 23. juni 2017 som NOU 2017:13 Ny sentralbanklov. Organiseringen av Norges Bank og Statens pensjonsfond utland. Eg vil i nokre notar kort omtale forslaga som gjeld punkt som er tatt opp i teksten. Gjedrem er elles ein sentral person i Lie mfl. 2016, sjå t.d. s. 435-437.

${ }^{86}$ Lovreguleringa av dette i dag er svært knapp. I lov om Statens pensjonsfond (2005 nr. 123) er det fastsett i $\S$ 2 andre ledd: «Statens pensjonsfond utland plasseres som innskudd på konto i Norges Bank. Motverdien forvaltes etter nærmere regler fastsatt av departementet, jf. § 7.» Dette er altså forma for Oljefondet - eit innskot i Noregs Bank. Det finst òg ei knapp regulering av eit underordna spørsmål i sentralbanklova § 5 tredje ledd: «Hovedstyret kan bestemme at virksomhet som ledd i forvaltningen av Statens pensjonsfond utland (SPU), jf. lov 21. desember 2005 nr. 123 om Statens pensjonsfond § 2 annet ledd, skal utøves av selskap som banken helt eller delvis eier. Hovedstyret representerer banken som eier i slike selskaper.» Dette er t.d. selskapet NBIM S.à.r.l., som er etablert i skatteparadiset Luxemburg for å handtere forvaltning av eigedomsinvesteringar.

${ }^{87}$ Lie m.fl. 2016: 459 og 443. Gjedrem-utvalet føreslår prinsipalt å skilje forvaltninga av Statens pensjonsfond utland heilt ut av Noregs bank og at det blir etablert eit særleg statsselskap som skal stå for forvaltninga.
} 
Norges Bank og forholdet mellom Norges Bank og statsmyndighetene». ${ }^{88}$ Som bakgrunn for utgreiingsarbeidet er det m.a. sagt: «Enkelte sider ved loven skiller seg fra tilsvarende lover i flere andre land.» Dei eksempla som her blir nemnde er svært velkjende for juristar både frå bank- og pengeretten og meir generell forvaltningsrett: «bl.a. bestemmelsene om bankens plikt til å forelegge saker av særlig viktighet for Finansdepartementet og om Kongens myndighet til å instruere banken». ${ }^{89}$ Dette gjeld spørsmål som naturleg nok var mykje drøfta før lova kom i 1985 og i juridisk teori etterpå. I sentralbanklova $§ 2$ tredje ledd står:

«Kongen i statsråd kan treffe vedtak om bankens virksomhet. Disse vedtak kan være generelle regler eller pålegg i enkeltsaker. Banken skal ha anledning til å uttale seg før det treffes slikt vedtak. Melding om vedtak skal sendes Stortinget snarest mulig.»

Denne føresegna legg altså kompetanse til å instruere berre til Kongen i statsråd, ikkje Finansdepartementet. Banken skal uttale seg først, og etterpå vil instruksen få særleg publisitet gjennom meldinga til Stortinget. ${ }^{90}$ Det grunnleggjande poenget er at dersom det er usemje mellom regjeringa og banken, skal ansvaret for ein eventuell instruks vere klart, og det skal leggjast til rette for ein offentleg diskusjon. Dette var måten Ryssdal-utvalet løyste balansegangen mellom uavhengig sentralbank og politisk kontroll. ${ }^{91}$ Skal ein lese mandatet til Gjedrem-utvalet slik at no skal det bli lettare å instruere, eller skal banken ikkje kunne instruerast lenger? ${ }^{92}$

\footnotetext{
Utvalet har og utarbeidd framlegg til korleis forvaltninga bør organiserast dersom Stortinget vedtar at den framleis skal liggje til banken, sjå NOU 2017: 13: 15-16 og 470-471, jf. 418-428 og 429-442.

88 Det er litt påfallande at ein i 2016 framleis skil mellom Noregs Bank og «statsmyndighetene», som på 1920og 1930-talet, jf. ovanfor ved note 54.

${ }^{89}$ Gjedrem-utvalet føreslår å oppheve plikta til å leggje fram saker «av særlig viktighet», sjå NOU 2017:13: 314 .

90 Om striden om instruksjonsretten, sjå Lie mfl. 2016: 403-404 og frå før sentralbanklova vart vedtatt, Smith 1980: 202-220, m.a. med tilvising til Torstein Eckhoff, Forvaltningsrett, Oslo 1978: 207, som, i motsetning til Smith, meinte det var gjeldande rett alt før 1985-lova at regjeringa hadde instruksjonsrett. Smith, som var medlem av Ryssdal-utvalet, meinte regjeringa burde få instruksjonsrett. Eckhoff heldt fast ved si oppfatning etter at Smiths bok var komen ut, sjå Torstein Eckhoff, Forvaltningsrett, 2. utg., Oslo 1982: 39 og 205.

${ }^{91}$ Per Christiansen viser til at instruksjonsheimelen berre synest vere brukt ein gong, ved den viktige fastsetjinga av forskrift ved kronprinsregentens resolusjon 29.03.2001 om at pengepolitikken heretter skulle styrast ut frå eit inflasjonsmål, ikkje berre ut frå valutakursen mellom norske kroner og euro. Men den gongen var det ikkje usemje mellom regjeringa og banken. Sjå Per Christiansen, Rentefastsettelse og instruksjonsmyndighet, i Peter Lødrup m.fl. (red.), Rettsteori og rettsliv. Festskrift til Carsten Smith, Oslo 2002: 167-182 på 170-172.

${ }^{92}$ Christiansen 2002: 181 meiner banken «bør gis en formell selvstendighet mer på linje med det som er vanlig i EUs medlemsstater». Men på det dåverande tidspunktet oppfatta Christiansen det òg slik at innføringa av euroen "etter sine egne forutsetning - er vellykket», s.st. 176. Gjedrem-utvalet føreslår å innskrenke instruksjonsretten til i enkeltsaker berre å gjelde i «ekstraordinære situasjoner», sjå kommentaren til utkastet $\S$ 1-4 andre ledd i NOU 2017:13: 495. Der blir det sagt at regjeringa ikkje bør kunne instruere sjølv om det er «faglig uenighet» mellom banken og regjeringa om korleis banken skal bruke sine verkemiddel for å nå dei fastsette måla. Banken skal altså bli rettsleg meir uavhengig.
} 
Utvalet skal òg sjå på samansetninga av hovudstyret der det i mandatet blir peikt på at hovudstyret i Noregs Bank no har fem eksterne medlemer, som altså ikkje arbeider heiltid i banken med spørsmåla. Dette er annleis enn i dei fleste land. Det blir særleg nemnt at i «flere andre land tas beslutninger av ekspertkomiteer med medlemmer som er ansatt i banken». Blir dette følgt opp, vil ein endeleg fullføre avviklinga av ordninga frå 1816 om at den øvste leiinga av banken skulle liggje hos personar som ikkje var i banken på fulltid. ${ }^{93}$

\section{Dei lange linjene}

Gjennom dei 200 åra sidan banken blei vedtatt oppretta, har dei rettslege spørsmåla kring Noregs Bank skifta. Men eit gjennomgåande spørsmål som har funne ulike løysingar, gjeld kor uavhengig skal det som etter kvart blei kalt sentralbanken, vere frå dei sentrale statlege styresmaktene. Det blei først løyst gjennom det private aksjeeigarskapet og organiseringa som aksjeselskap. Då aksjeselskapsforma blei oppheva i 1985, søkte ein i staden å utvikle særlege reglar om instruks frå regjeringa og å halde på balansen mellom regjeringsoppnemnt hovudstyre der dei fleste medlemene var eksterne, medan Stortinget framleis oppnemnde heile representantskapet. No skal begge desse ordningane vurderast på nytt av Gjedremutvalet.

På nokre få punkt har det vore kontinuitet. Representantskapet har framleis femten medlemer som i 1816, og som i Den dansk-norske Speciesbank før det. ${ }^{94}$ Også setelmonopolet har vore kontinuerleg frå 1818.

Grunnlovsspørsmåla som banken har reist, har skifta. Så lenge det var private eigarar, gjaldt spørsmåla kva for vern dei hadde for den økonomiske verdien av sin posisjon i medhald av dei sentrale grunnlovsparagrafane 97 og 105. Etter at banken blei statseigd, var det i staden spørsmål om den då blei omfatta av grunnlova $§ 19$, som regulerer forholdet mellom regjering og storting, typisk når det gjeld retten for regjeringa til å instruere banken. Og så har det vore eit comeback for banken sjølv i grunnlova. Den var omtalt, men ikkje namngitt, frå hausten 1814 til 1911, og no igjen med eigen paragraf frå 2016. Den gamle føresegna var eit

\footnotetext{
${ }^{93}$ Gjedrem-utvalet kastar om på dette og føreslår eit særskilt styre for banken med berre eksterne representantar, meir på linje med eit vanleg aksjeselskapsstyre, og ein særskild komité for pengepolitikk og stabilitet med avgjerdskompetanse og som er samansett av folk frå banken og ekspertar utanfrå. Den er leia av sentralbanksjefen. Dette er inspirert av ordninga i andre sentralbankar, sjå NOU 2017:13: 387-392.

${ }^{94}$ Som del av den omfattande omorganiseringa som blir føreslått, gjer Gjedrem-utvalet framlegg om å oppheve representantskapet, sjå NOU 2017:13: 404.
} 
vern mot unionspartnar Sverige, medan den nye nok har mest eit pedagogisk føremål, men kanskje ikkje berre.

Ei lang linje som viser eit skift i oppfatninga av banken, er det vel òg i kven som har leia utarbeiding av den generelle Noregs Bank-lovgivinga. Den første komiteen som skreiv lov var leia av den markerte embetsmannen og politikaren og seinare finansminister, grev Wedel, den andre leia av politikaren og seinare stats- og finansminister Johannes Steen. Så blei leiarskapet mindre politisk markert. Komiteen som utarbeidde sentralbanklova av 1985, var leia av høgsterettsjustitiarius Rolv Ryssdal. Og det nye lovutvalet no er leia av ein innsider, tidlegare sentralbanksjef og finansråd Gjedrem. Kanskje viser dette at banken igjen blir meir heva opp over politikken? 